\title{
LEVERAGE, COST OF CAPITAL AND BANK VALUATION
}

\author{
FEDERICO BELTRAME*,\$, STEFANO CASELLI ${ }^{\dagger, \pi}$ and \\ DANIELE PREVITALI ${ }^{\$}, \|$ \\ *University of Udine, Department of Economics and Statistics, \\ Via Tomadini 30/a, 33100, Udine, Italy \\ ${ }^{\dagger}$ Bocconi University, Department of Finance, \\ Via Sarafatti 25, 20136, Milan, Italy \\ $\star$ Luiss University, Department of Business and Management, \\ Viale Romania 32, 00198 Rome, Italy \\ §federico.beltreme@uniud.it \\ 『stefano.caselli@unibocconi.it \\ "dprevitali@luiss.it
}

Accepted 2 May 2018

Published 7 June 2018

\begin{abstract}
In this paper, we present a model that demonstrates the effect of debt on cost of capital and value in the case of banking firms. Using a static partial equilibrium setting, both in a steady state and steady growth scenario, we derive a bank-specific valuation metric which separately attributes value to assets and debt cash flows in the form of a liquidity premium and taxshield. We run our model on a sample of the largest 26 European banks from 2003 to 2016 finding that the value contribution of debt benefits to enterprise value is large and persistent. Further from our model, we derived an implied cost of capital (ICC) measure finding consistent results with capital asset pricing model (CAPM). The theoretical framework we present is helpful to address bank debt benefits valuation and to reconcile equity and asset side approaches.
\end{abstract}

Keywords: Bank valuation; capital structure; cost of capital; liquidity premium; taxes.

JEL Classifications: D58, G21, G31, G32

\section{Introduction}

Banks represent a particular case in valuation, as they create value from both the assets and liabilities side of their balance sheet due to the liquid-claim production (De Angelo \& Stulz 2015, Hanson et al. 2015). This peculiar and unique feature of

$\|_{\text {Corresponding author. }}$

This is an Open Access article published by World Scientific Publishing Company. It is distributed under the terms of the Creative Commons Attribution 4.0 (CC-BY) License. Further distribution of this work is permitted, provided the original work is properly cited. 
banks has several important side-effects on the cost of capital and total value as a whole (Hanson et al. 2011, Kashyap et al. 2010).

Although the effect of the liquid-claim production on debt has been widely acknowledged and investigated in the banking literature (among others: Diamond \& Dybvig 1983, Diamond \& Rajan 2001, Gorton 2010, Gorton \& Pennacchi 1990, Holmström \& Tirole 2011), from a corporate finance perspective, less effort has been made in identifying a bank-specific DCF valuation model which can highlight the effects of bank debt on cost of capital and enterprise value. More in detail to the knowledge of the authors, no contribution concerned specifically the stand-alone valuation of debt benefits and the related discount rate in the banking industry, whereas in other industrial sectors it has been investigated by various scholars (among others: Fernández 2004, Arzac \& Glosten 2005, Cooper \& Nyborg 2006).

This paper seeks to fill this gap, moving beyond the adjusted present value (APV) model used by Beltrame \& Previtali (2016), which contributes to explain how assets and debt cash flows create value in baking. In particular, we first check the feasibility of the APV model, analyzing the compatibility between its basic assumptions and the intermediation role of banking firms. Second, we discuss the risk profile of debt benefits and suggest a reconciliation equation between asset and equity side DCF approaches in banking. Third, we discuss the cost of capital implications for different growth scenarios. Finally, we apply our model to a sample of the largest European banks to show, on one hand, that debt benefits contribution to enterprise value is large and persistent, on the other hand, that the implied cost of capital (ICC) estimation we derived from our model is consistent with the capital asset pricing model (CAPM).

The most used approach to bank valuation focuses on equity, whereas for other sectors, asset-side models are the most widely used metric (Barker 1999, Imam et al. 2008). This convergence toward equity-side approach for banks valuation is mainly due to the liquidity premium banks hold on deposits which entails several issues when estimating operating cash flows and interpreting weighted average cost of capital (Copeland et al. 2000, Damodaran 2013, Massari et al. 2014). The model we propose in this paper aims at overcoming such issues by building an asset-side method to banks valuation, with separate valuation of debt benefits.

In an asset-side approach, firm value is obtained using two alternatives: (a) discounting free cash flow from operations at the weighted average cost of capital (the aggregate model); and (b) discounting free cash flow from operations at the unlevered cost of equity, and adding, separately, the present value of tax savings (the disaggregate model, widely known as APV approach (Myers 1974) or, in a modified version, as the capital cash flow (CCF) method (Ruback 2002)). The disaggregate model exploits the well-known debt-value relation proposed in the seminal papers of Modigliani \& Miller (1958, 1963; hereafter MM) and enables to split clearly the effects of investing and financing decisions on total value. In the case of banks, given the production of liquid-claims and the associated value creation on the liabilities side, a disaggregate model could be a useful solution for highlighting debt benefits and cost of capital implications. A disaggregate asset-side view is not new in the 
banking literature. Bank \& Lawrenz (2013), focusing on the optimal mix of bond and deposit financing, used a trade-off model in which the levered value of a bank is obtained by increasing and decreasing the bank unlevered value by the advantages and disadvantages on debt, respectively. More recently, Hanson et al. (2015) defined bank value as the sum between the actualized expected cash flows on assets and money-premium on deposits.

However, the main critical issue in dealing with in the application of a DCF disaggregate model in a banking context is its consistency with the theories of MM. First, the extension of MM's propositions is debatable because of the incompatibility of the assumptions underlying the theoretical framework of the theorems due to the role of banks in reducing information asymmetries in a MM's world. Second, more technically, a formal restatement of MM's first and second propositions is problematic as one cannot separate operating from financial management both in terms of cash flows and cost of capital. In order to overcome these issues, a formal restatement of MM's propositions for banking firms exploiting the segmented-markets model has been put forward allowing for the existence of banks in a perfect and complete financial market (Merton 1990, De Angelo \& Stulz 2015), assuming initially the existence of liquidity premium on deposits, no taxes and no distress costs. In addition, the model has been developed also considering the presence of liquidity premiums and taxes, but continuing to assume the absence of costs of distress.

In this paper, using a static partial equilibrium model as in Modigliani \& Miller (1958), we separate the contribution of assets from liabilities, in line with the original framework of disaggregate models for non-financial firms. The model we propose helps to directly and explicitly reveal the value creation determinants of banks by providing a more general leverage-cost of capital theory in the absence of distress costs.

The use of a disaggregate asset-side model for banks can help to overcome typical problems of DCF aggregate models and, in particular, cost of equity and weighted average cost of capital redetermination when leverage changes over time. In the case of banks, exogenous changes in regulatory capital ratios imposed by Authorities have strong impact on market debt to value ratio and cost of capital. When these changes occur, an APV approach, appropriately modified to take into account of the bank debt's benefits represents a viable solution to avoid both the cost of equity redetermination and or valuation errors occurring when the managers and analysts decide to maintain stable the discount rate in the DCF equity side methods (such as the most widely used dividend discount model).

Besides assuming a disaggregate view of value, the model also provides a sort of binary approach to bank valuation which is useful in taking into account their specifics on the asset and liabilities side. On the one hand, the model assigns a portion of value to assets in relation to their cash flows and expected return. On the other hand, the disaggregate approach explicitly attributes a significant portion of value to banks' debt when they better manage financial structure in terms of composition and pricing. 
A separated view of value also allows to analyze the cost of capital implications over banks' debt management strategies. The theoretical framework presented in this paper offers an explanation in terms of value on why banks hold an incentive to fund their assets through deposits or other marked-down financial instruments. The liquidity premium gained on this type of debt instruments mitigates the effect of the cost of increasing leverage on cost of equity, with direct effects in terms of valuation. Thus, in the presence of macroeconomic conditions where banks retain wide margins on mark-down management and in the absence of distress costs, the higher the stock of marked-down debt, the greater the value creation.

On the whole, this paper contributions to the literature are several. It provides a theoretical framework for banks valuation which reconciles asset and equity side approaches, thereby removing the drawbacks of currently applied valuation models. Besides, it offers empirical evidence that banks might have value even if assets destroy value because of the debt intrinsic benefits. Furthermore, it derives an assetside ICC estimation which is consistent with the CAPM but with the advantage of being easier to implement and using few discretional inputs.

The remainder of the paper is organized as follows. The next section introduces the theoretical model. Section 3 introduces a bank valuation framework in a steady state and in a steady growth scenario and discusses implications of the cost of capital. Section 4 compares equity and asset side methods in terms of banks' capital structure. Section 5 presents the results of the empirical application of the model and Section 6 concludes.

\section{Capital Structure and Bank Total Value}

The effect of leverage on firm value and cost of equity are usually analyzed in the light of MM's propositions. If the leverage irrelevance principle is valid for banking firms as predicted by the first proposition, a variation of financial leverage would imply a proportional variation in the cost of equity, maintaining the overall cost of funding stable. The agreed view in the literature is that MM's theorems cannot be applied to banks in perfect and complete financial markets, because the absence of information asymmetries makes unnecessary the presence of financial intermediaries (Mehran \& Thakor 2011). De Angelo \& Stulz (2015) offer a viable solution for such alleged incompatibility introducing a segmented-markets model (Merton 1990) which assumes two financial markets with different levels of information availability: a first perfect and complete financial market and a second financial market with frictions. In their model, banks act in the first market, and at the same time, extend loans to agents in the second financial market, maintaining their role in reducing information asymmetries between agents, following MM's assumptions.

With regard to investigating the effect of financial structure on value, MM require a clear split between operating and financial cash flows. But this cash flow breakdown is not easily achieved, because for banks financial management is part of operating management. In order to overcome this problem, we reconsider cash flow 
generation and separate cash flows from assets and liabilities. In asset cash flows, we take into account not only the positive components arising from loans and securities, but also the negative components related to intermediation costs, which depend on bank scale and size (De Angelo \& Stulz 2015).

Combining the segmented financial market assumption and the distinction between asset and debt cash flows, a static partial equilibrium model to analyze the effect of leverage on bank value is exploited.

\subsection{A static partial equilibrium model for banks}

Consider two banks with the same class of risk and the same operating expected return $(\mathrm{X})$ given by the net profit of the intermediation activity, before the deduction of financial expenses paid on debt. Both banks operate in the first perfect and complete financial market, and are intermediaries on the second, imperfect and incomplete financial market. Bank 1 is financed only by equity $\left(S_{1}\right)$, while Bank 2 has a financial structure composed of equity $\left(S_{2}\right)$ and safe debt in the form of deposits $\left(D_{2}\right)$. Bank 2 gains a liquid-claim premium $(p)$, which is equal to the difference between the perfect and complete market interest rate $\left(r_{f}\right)$ (risk-free) and the liquid financial claim interest rate $\left(r_{l}\right)$. Specifically, the liquidity premium is reached paying debt at $r_{l}$ rather than $r_{f}$, with $r_{l}<r_{f}$.

The existence of the two different interest rates in a frictionless market is justified by the presence of intermediation costs: they eliminate arbitrage across the two markets and, consequently, make a liquidity-claims rate lower than risk-free rate possible. On this basis, according to the seminal work of Modigliani \& Miller (1958), it is possible to demonstrate that for an agent operating in a first perfect and complete financial market, different financial strategies lead to the same bank value in equilibrium.

\subsection{1. "Homemade leverage" strategy}

If an investor holds a fraction $\alpha$ of Bank 2 equity, its return $Y_{2}$ would be equal to:

$$
Y_{2}=\alpha\left(X-r_{l} D_{2}\right) \text {. }
$$

The same investor could replicate the capital structure of Bank 2 selling his stocks, borrowing on his own credit an amount of debt equal to $\alpha D_{2}$ and purchasing on the market an amount of equity of Bank 1 equal to $\alpha\left(S_{2}+D_{2}\right)$. He would thus acquire a percentage of equity equal to $\alpha\left(S_{2}+D_{2}\right) / S_{1}$.

The return $Y_{1}$ for the so-called "homemade leverage" strategy would be equal to:

$$
Y_{1}=\alpha \frac{V_{2}}{V_{1}} X-r_{f} \alpha D_{2}
$$

where $S_{2}+D_{2}$ is equal to $V_{2}$ and $S_{1}$ is equal to $V_{1}$, while $r_{f}$ is the interest rate paid on debt by the investor himself in a perfect and complete market. The investor would 
have the incentive to sell his stocks of Bank 2 and purchase stocks of Bank 1 only when $Y_{1}>Y_{2}$ and until the increase in Bank 1 equity and the decrease in Bank 2 equity make equal the return on Bank 2 with the return on "homemade leverage" strategy $\left(Y_{1}=Y_{2}\right)$ :

$$
\alpha\left(X-r_{l} D_{2}\right)=\alpha \frac{V_{2}}{V_{1}} X-r_{f} \alpha D_{2} .
$$

\subsection{2. "Mixed portfolio" strategy}

If the investor holds a fraction $\alpha$ of Bank 1 (unlevered) equity, its return $Y_{1}$ would be equal to:

$$
Y_{1}=\alpha X
$$

The investor can switch all his equity unlevered portfolio to a mixed portfolio (comprising equity and debt) selling his stocks and acquiring a proportional amount of equity of Bank 2 equal to $\frac{V_{1} \alpha}{V_{2}} S_{2}$ and an amount of debt of $\frac{V_{1} \alpha}{V_{2}} D_{2}$. As long as the investor acts in a perfect and complete financial market, he would be able to achieve an interest rate on debt equal to the risk-free rate, rather than the lower interest rate obtained by agents of the imperfect and incomplete financial market. Therefore, the total return on the mixed portfolio (on equity and debt $-Y_{2}$ ) is:

$$
Y_{2}=\frac{V_{1} \alpha}{V_{2}}\left(X-r_{l} D_{2}\right)+r_{f} \frac{V_{1} \alpha}{V_{2}} D_{2} .
$$

The first term of (2.5) represents the yield on equity and the second term the yield on debt. The investor would have the incentive to sell his stocks in Bank 1 and acquire stocks of Bank 2 if $Y_{2}>Y_{1}$ and until the increase of Bank 2 equity and the decrease of Bank 1 equity makes equal the return on Bank 1 with the return on mixed portfolio strategy $\left(Y_{1}=Y_{2}\right)$ :

$$
\alpha X=\frac{V_{1} \alpha}{V_{2}}\left(X-r_{l} D_{2}\right)+r_{f} \frac{V_{1} \alpha}{V_{2}} D_{2}
$$

\subsection{Leverage effect on bank value}

Expressed in terms of $V_{2}$, both (2.3) and (2.6) lead to (2.7) in equilibrium:

$$
V_{2}=\frac{V_{1}}{X} D_{2}\left(r_{f}-r_{l}\right)+V_{1}
$$

We can now define $V_{1} / X$ as the factor of proportionality $1 / \rho_{1}$ or the inverse of expected rate of return, that is, the cost of equity for the unlevered bank associated with a specific class of risk. Hence, (2.7) is formally MM's first proposition when deposits are priced considering a liquidity premium $\left(r_{f}-r_{l}\right)$, in line with the view of Hanson et al. (2015) on traditional banks. Accordingly, the more a bank levers up, other things remaining equal, the higher the bank firm value. Note that if the 
bank does not gain a liquidity premium, the interest rate on debt is the same as the market rate $\left(r_{f}=r_{l}\right)$. As a consequence, the enterprise value of the unlevered bank (Bank 1) and levered bank (Bank 2) are equivalent and MM's leverage irrelevance principle still holds true. On the other hand, if Bank 2 issues debt at lower rates than the market rate $\left(r_{f}-r_{l}=p>0\right)$, then the enterprise value of the levered bank will be higher than the unlevered bank $\left(V_{2}>V_{1}\right)$. In this case, debt will be the preferred source of funding and, consequently, the leverage irrelevance principle does not hold.

If (2.7) is re-expressed as a function of the unlevered cost of capital, the enterprise value of the bank would be equal to:

$$
V_{2}=D_{2} \frac{\left(r_{f}-r_{l}\right)}{\rho_{1}}+\frac{X}{\rho_{1}} .
$$

The first term of the equation is the Present Value of Liquidity Premium (PVLP), while the second term is the bank's asset cash flow discounted at the cost of capital of the unlevered bank in a steady state framework.

In a perfect and complete financial market, banks can transform risky assets to riskless assets by following a policy of hedging. On this basis, our model would converge to that of De Angelo \& Stulz (2015) in which free cash flows to equity (and as a consequence the asset cash flow) are discounted at the risk-free rate. However, the bank's firm value does not only depend on the value of its assets, but also on the value created by other financial services such as investment banking and the many other activities that banks typically undertake to increase profits. The risk associated with this type of businesses cannot be totally eliminated through hedging strategies, so the discount rate of these cash flows should be higher than the risk-free rate.

Thus, in a similar manner to MM's application for nonfinancial firms, asset cash flows should be discounted at $\rho_{1}>r_{f}$. The presence of risky assets implies a lower capacity of issuing safe debt. In fact, banks could lever up without losing the liquidity premium until debt is equal to the value of perfectly hedged assets and, as a consequence, less than $100 \%$ of its enterprise value. The same conclusion is reached by De Angelo \& Stulz (2015) for cases when only an imperfect hedging strategy is possible, which makes capital requirements useful to cover unexpected losses.

\section{Leverage, Cost of Capital and Valuation for Banking Firms}

In line with an asset-side disaggregate valuation model used for non-financial firms, the bank valuation scheme proposed in the previous section separates the unlevered bank value from debt benefits. Specifically, in the case of industrial firms, the assetside disaggregate model determines the enterprise value as the sum between the value of the unlevered firm and the value of tax benefits of debt. In the case of banks, as noted above, debt creates value not only through the deductibility of interest expenses, but also by a liquidity premium on deposits. 
In this section, it is presented that the bank valuation model takes into account both the tax and liquidity premium benefits in two configurations: the steady state and the steady growth scenarios. In each scenarios, the authors make distinct assumptions on the discount rate for the benefits of debt. Since debt benefits discount rate should be included in a range between the cost of debt (in which the risk-free rate is the minimum reference) and the cost of asset (Massari \& Zanetti 2008), both valuations are presented in the following section. The approaches they introduce have different implications in terms of weighted average cost of capital and cost of equity.

\subsection{The steady state valuation}

Following MM, we can choose to discount the fiscal and liquidity premium benefits using the unlevered cost of equity (Modigliani \& Miller 1958) or the cost of debt (Modigliani \& Miller 1963). In the first case, debt benefits in the form of both liquidity premium and tax-shields are discounted at the cost of capital for the unlevered bank. Thus (2.8) becomes:

$$
V_{2}=\mathrm{PVLP}+\mathrm{PVTS}+V_{1}=D_{2} \frac{\left(r_{f}-r_{l}\right)}{\rho_{1}}+D_{2} \tau \frac{r_{l}}{\rho_{1}}+\frac{X^{\tau}}{\rho_{1}},
$$

where PVLP is the Present Value of Liquidity Premium, PVTS is the Present Value of Tax Shield, $\tau$ is the tax rate and $X^{\tau}$ is the net bank's assets cash flow before interest expenses. According to Hanson et al. (2015), the interest rate on liquidclaims is calculated as the interest rate on deposits divided by deposits. More concisely, Eq. (3.1) can be written as

$$
V_{2}=\mathrm{PVDB}+V_{1}=D_{2} \frac{\left[r_{f}-r_{l}(1-\tau)\right]}{\rho_{1}}+\frac{X^{\tau}}{\rho_{1}},
$$

where PVDB is the Present Value of Debt Benefits (the sum of PVLP and PVTS) while $V_{1}$ is the unlevered bank value. As we noted above, the valuation approach provides a useful independent view of bank value, enabling us to understand the contribution of assets, liquidity premium and tax-shields to the enterprise value of a bank. However, as in the case of non-financial firms, this valuation model should be equivalent to an asset-side aggregate model in which free cash flows are discounted at the weighted average cost of capital $\left(\rho_{2}\right)$ whereby debt benefits are included in the discount rate:

$$
V_{2}=\frac{X^{\tau}}{\rho_{2}}
$$

It has been demonstrated that the aggregate model leads to the same result as the disaggregate model when benefits from tax-shields are discounted at the unlevered cost of equity (Ruback 2002). Thus, adapting the traditional relation between weighted average cost of capital and unlevered cost of equity to the case of banking 
firms, the relation between $\rho_{2}$ and $\rho_{1}$ can be written as

$$
\rho_{2}=\rho_{1}-\frac{D_{2}}{V_{2}}\left[r_{f}-r_{l}(1-\tau)\right] .
$$

Other things remaining equal, $\rho_{2}$ decreases when leverage increases more than proportionally according to the size of liquidity premium and taxes effect (Hanson et al. 2011, Kashyap et al. 2010). The model is also consistent with an equity-side model. In this case, the value of a bank can be measured as

$$
S_{2}=\frac{Y_{2}}{i_{2}}
$$

where $i_{2}$ is the cost of equity. Combining (3.4) with the traditional weighted average cost of capital formula (3.6):

$$
\rho_{2}=i_{2} \frac{E_{2}}{V_{2}}+r_{l}(1-\tau) \frac{D_{2}}{V_{2}}
$$

the cost of equity $i_{2}$ consistent with the valuation approach proposed is obtained:

$$
i_{2}=\rho_{1}+\left(\rho_{1}-r_{f}\right) \frac{D_{2}}{S_{2}} .
$$

Equation (3.7) is the second proposition of MM. As in the case of non-financial firms, when bank debt benefits are discounted using the cost of unlevered firm, the cost of equity is not directly dependent on the tax rate and liquidity premium.

As in the case of Modigliani \& Miller (1963) and in line with the original APV approach of Myers (1974), debt benefits are both discounted at the risk-free rate (the cost of debt) and therefore Eq. (3.1) becomes

$$
V_{2}=\mathrm{PVLP}+\mathrm{PVTS}+V_{1}=D_{2} \frac{\left(r_{f}-r_{l}\right)}{r_{f}}+D_{2} \tau \frac{r_{l}}{r_{f}}+\frac{X^{\tau}}{\rho_{1}}
$$

and the concise version of the valuation model (Eq. (3.2)) becomes:

$$
V_{2}=\mathrm{PVDB}+V_{1}=D_{2}\left[\frac{r_{f}-r_{l}(1-\tau)}{r_{f}}\right]+\frac{X^{\tau}}{\rho_{1}} .
$$

The weighted average cost of capital and the cost of equity consistent with the use of cost of debt to discount tax benefits and liquidity premium, are respectively:

$$
\begin{aligned}
& \rho_{2}=\rho_{1}\left[1-\frac{D_{2}}{V_{2}} \frac{r_{f}-r_{l}(1-\tau)}{r_{f}}\right], \\
& i_{2}=\rho_{1}+\left(\rho_{1}-r_{f}\right)(1-\tau) \frac{r_{l}}{r_{f}} \frac{D_{2}}{S_{2}},
\end{aligned}
$$

where Eq. (3.11) is the reinterpretation of MM's work with taxes integrated with the liquidity premium. All other things remaining equal, the larger the difference between the risk-free rate and the pricing of deposits, the flatter the effect of leverage on cost of equity. 


\subsection{The steady growth valuation model}

In the case of growth too, we can assess banks' debt benefits by discounting either using the unlevered cost of equity (Dempsey 2013) or the cost of debt (Massari et al. 2008).

Thus, considering a constant growth rate both for asset and debt, following Dempsey (2013), (3.1) becomes

$$
V_{2}=\mathrm{PVLP}+\mathrm{PVTS}+V_{1}=D_{2} \frac{\left(r_{f}-r_{l}\right)}{\rho_{1}-g}+D_{2} \tau \frac{r_{l}}{\rho_{1}-g}+\frac{X^{\tau}}{\rho_{1}-g}
$$

and (3.2) becomes

$$
V_{2}=\mathrm{PVDB}+V_{1}=D_{2} \frac{\left[r_{f}-r_{l}(1-\tau)\right]}{\rho_{1}-g}+\frac{X^{\tau}}{\rho_{1}-g} .
$$

Apart from the steady state hypothesis, $X^{\tau}$ should consider not only bank margins but also the negative effect of additional investments, in order to maintain a certain level of growth. Also in the steady growth scenario, the model must be consistent with both the aggregate model and with the equity-side approach. In the case of the aggregate model, bank value is equal to

$$
V_{2}=\frac{X^{\tau}}{\rho_{2}-g} .
$$

The weighted average cost of capital making equal the value obtained through (3.13) with that obtained through (3.14) is reached using the same formula as the steady state framework (Miles \& Ezzell 1980, Dempsey 2013):

$$
\rho_{2}=\rho_{1}-\frac{D_{2}}{V_{2}}\left[r_{f}-r_{l}(1-\tau)\right]
$$

Thus, when debt benefits are discounted at the unlevered cost of capital, growth does not affect the weighted average cost of capital.

For the equity-side approach too, we can assess the value of equity discounting the expected free cash flow to equity at the difference between the cost of equity and the growth rate:

$$
S_{2}=\frac{Y_{2}}{i_{2}-g} .
$$

As it is noted, the cost of equity in a growth scenario is calculated as by MM in their second proposition without taxes:

$$
i_{2}=\rho_{1}+\left(\rho_{1}-r_{f}\right) \frac{D_{2}}{S_{2}} .
$$

Conversely, following Massari et al. (2008), our model becomes:

$$
V_{2}=D_{2} \frac{\left[r_{f}-r_{l}(1-\tau)\right]}{r_{f}-g}+\frac{X^{\tau}}{\rho_{1}-g} .
$$


Accordingly, the weighted average cost of capital (3.10) and cost of equity (3.11) must be restated for the growth scenario. Combining (3.18) with (3.14), we find the relation between the weighted average cost of capital and the unlevered cost of capital

$$
\rho_{2}=\rho_{1}-\frac{\rho_{1}-g}{r_{f}-g}\left[r_{f}-r_{l}(1-\tau)\right] \frac{D_{2}}{V_{2}}
$$

and combining (3.19) with (3.15), we restate the cost of equity as

$$
i_{2}=\rho_{1}+\left(\rho_{1}-r_{f}\right) \frac{D_{2}}{S_{2}}\left[\frac{r_{l}(1-\tau)-g}{r_{f}-g}\right] .
$$

Unlike the previous version of the model, in this version, the weighted average cost of capital and the cost of equity are affected by taxes, liquidity premium and growth rate.

\subsection{Choosing the appropriate discount rate for debt benefits}

The debt benefits stand-alone valuation requires the choice of the appropriate discount rate for tax-shields and liquidity premium. In the case of fiscal benefits arising from debt, the literature on industrial firms recommends using cost of debt in the steady state hypothesis (Modigliani \& Miller 1963, Myers 1974) and, conversely, the unlevered cost of capital in the steady growth hypothesis (Dempsey 2013). In the first case, when debt is kept fixed over time, Modigliani \& Miller (1963) justify the use of the cost of debt rather than the unlevered cost of capital, claiming the risk profiles for firms' operating and tax-shield cash flows are different. The operating cash flow is uncertain and dependent on the risk associated to assets, while the tax-shield cash flow is the result of a determined stock of debt. In the second case, when the dynamic of debt is in line with that of the free cash flow from operations (and with the same expected growth rate), the literature discounts the tax benefits using the unlevered cost of capital (Cooper \& Nyborg 2006, Dempsey 2013, Harris \& Pringle 1985, Miles \& Ezzell 1980, Ruback 2002). However, the choice depends on the assumption about future debt policy. If it is assumed that debt-to-value ratio will remain stable in the forecast period, the discount rate should be equal to the cost of debt. Alternatively, assuming a constant debt-to-value ratio in the case of steady growth, the appropriate discount rate should be equal to that of asset cash flows.

With regards to banks, although there are no explicit references in the literature to stand-alone valuation of debt benefits, empirical models used to investigate the effect of capital requirements on systematic risk implicitly take the cost of unlevered capital as the discount rate for debt benefits (Baker \& Wurgler 2015, Miles et al. 2013). This is because it is assumed that additional cash flows due to debt undergo the same risk as operating assets. This perspective is widely endorsed by the literature, which considers bank debt to be operational rather than financial in nature (among others: Massari et al. 2014). However, these different views on bank debt 
should not lead to treating it as working capital. Although the bank debt instruments hold an operational nature, their contractual representation is equivalent to that of financial debt in other industrial companies. Consequently, it should maintain its function as a stable source of funding even when it holds benefits in terms of value creation.

\section{Comparing Asset and Equity Cash Flow Method: The Capital Structure Effect}

Empirical evidence suggests a positive correlation between leverage and bank cost of equity, in both systematic and specific risk frameworks. Among others, Kashyap et al. (2010) highlight a negative relation between book equity to asset ratio and equity beta, while Miles et al. (2013) confirm the same results finding a similar relation using the inverse of price-earning ratio as a measure of cost of equity. Moreover, the relation is still valid using beta or equity standard deviation and both book and market leverage ratios (Rosenberg \& Perry 1978).

Given the empirical evidence that leverage has a significant effect on banks' cost of equity, the valuation approach needs to consider the dynamics of debt and equity in order to assess how the financial structure affects value in the absence of distress costs. The choice in terms of leverage is not negligible in banking because, in addition to affecting the cost of capital, leverage is closely monitored by the Basel framework which sets specific limitations on the bank's ability to take on debt. Although capital requirements and leverage are regulated, banks can choose to operate with different financial structures and may opt to set their requirements above regulation levels or near to minimum requirements. But such relative small differences can have substantial effects in terms of valuation.

The asset cash flow method introduced in this paper offers a potential solution to the problem of the hypothesis of constant debt to value ratio proper of DCF equity side metrics almost universally applied in banking valuation. In an infinite time horizon the assumption might be a reliable estimation, but in an explicit forecast period, the capital structure can no longer be constant (Taggart 1991), making the capital structure stability a too simplistic assumptions in many circumstances (e.g. in the case of leverage buy-out operations). In the case of banks, a stable capital can be an even more problematic assumption, since change in leverage does not depend only by management and shareholders' choices but also by exogenous variables. The same problem arises if we implement an aggregate asset side valuation (WACC approach) since the discount rate is affected by the leverage ratio due to the presence of taxes and liquidity premium.

The cost of equity and weighted average cost of capital redetermination process require a basic market leverage-cost of capital theory for banking firms, which it has been introduced in Section 3. Alternatively, the problem can be resolved applying directly the disaggregate asset cash flow method, because it does not require the 
market leverage ratio as an input and is more appropriate when target leverage ratios are linked to regulatory measures. Thus, precise assumptions can be made about the dynamic of bank debt in the analytic forecast period (Inselbag \& Kaufold 1997). More generally, if a leverage-consistent valuation for banks is required, our model allows us to move from an asset to equity side approach, still considering the effects of changes in financial structure on cost of capital and value.

\section{The Dynamics of the Benefits on Debt and the Cost of Capital: An Analysis of the Major European Banks}

Compared to the models currently used for the valuation of banks, the model presented in this paper enables to obtain estimates of how much of the value is generated by assets and how much is generated by debt. In addition, the cost of assets implied in the market value of stocks can be extrapolated through it. This represents an element of innovation in the related literature since, according to our model, a bank may have a value greater than zero even when assets destroy value.

In this section, we use the model we presented in this paper to estimate and analyze the dynamics of the value generated by debt on a sample of the major European banks (26 credit institutions) over a time horizon of 14 years, from 2003 to 2016. We compared the value of debt benefits to the market value of assets and riskfree in the Euro area to show how value creation on the liabilities side is greater than assets and it is correlated to the monetary and fiscal policy.

Secondly, we compare the cost of assets estimations obtained using the Capital Asset Pricing Model (CAPM) with the ICC obtained using our model. Results show how our model provides an easier instrument to price assets than CAPM.

\subsection{Sample and data}

In our analysis, we selected the major European listed banks which, as at 1st January 2018, were under the European supervision of the ECB and for which data were available. The time horizon of the analysis is 15 years, from 2003 to 2017 . For some banks, the 2017 data were not yet available at the time this paper was written. The analyses were then concentrated from 2003 to 2016 .

The sample consists of 26 banks with assets over 50 billion euro (Table 1). Market and balance sheet data were extracted from Bloomberg database, while the marginal tax rate from the OECD website. As far as the cost of capital is concerned, risk-free have been estimated by using yearly-average of the 10-year bonds yields of the main domestic market. Beta equity is measured in relation to the Eutostoxx 600 considering weekly returns for the last 5 years from the valuation date. In order to avoid discretional biases in valuations, the Market Risk Premium (MRP) was set at $5 \%$ in line with the historical method of estimating assets at risk with respect to risk-free assets. We also tried to reconstruct alternative estimates of MRP using the survey method and found several shortcomings in some of the years under investigation. 
Table 1. The sample.

\begin{tabular}{|c|c|c|c|}
\hline No. & Bank & Market & Total asset 2016 (mil $€)$ \\
\hline 1 & BNP Paribas & France & 2.076 .959 \\
\hline 2 & Deutshe Bank & Germany & 1.590 .546 \\
\hline 3 & Credit A gricole & France & 1.524 .232 \\
\hline 4 & Societe Generale & France & 1.382 .241 \\
\hline 5 & Santander & Spain & 1.339 .125 \\
\hline 6 & Unicredit & Italy & 859.533 \\
\hline 7 & ING & Netherland & 845.081 \\
\hline 8 & BBVA & Spain & 731.854 \\
\hline 9 & Intesa SanPaolo & Italy & 725.100 \\
\hline 10 & Commerzbank & Germany & 480.450 \\
\hline 11 & CaixaBank & Spain & 347.927 \\
\hline 12 & $\mathrm{KBC}$ & Belgium & 275.200 \\
\hline 13 & Dexia & Begium & 212.771 \\
\hline 14 & Banco de Sabadell & Spain & 212.508 \\
\hline 15 & Erste & Austria & 208.227 \\
\hline 16 & Banca Montepaschi di Siena & Italy & 153.178 \\
\hline 17 & Raifffeisen Bank International & Austria & 111.864 \\
\hline 18 & Piraeus Bank & Greece & 81.501 \\
\hline 19 & National Bank of Greece & Greece & 78.531 \\
\hline 20 & Banco Comercial Portugues & Portugal & 71.265 \\
\hline 21 & Mediobanca & Italy & 69.819 \\
\hline 22 & Bankinter & Spain & 67.182 \\
\hline 23 & Eurobank Ergasias & Greece & 66.393 \\
\hline 24 & BPER & Italy & 64.957 \\
\hline 25 & Alpha Bank & Greece & 64.872 \\
\hline 26 & Banca Popolare di Milano & Italy & 51.131 \\
\hline
\end{tabular}

\subsection{Methods}

Using our model and given the bank enterprise value, the cash flow and cost of the assets, we quantify the value generated by the tax benefits and liquidity premium (PVDB) as:

$$
\mathrm{PVDB}=V_{2}-\frac{X^{\tau}}{\rho_{1}}
$$

where $V_{2}$ is the bank enterprise value (the sum of market capitalization and debts), $X^{\tau}$ is the free cash flow from assets (FCFA), indirectly obtained adding back the interest expenses net of the tax effect to normalized net income. $\rho_{1}$ is obtained through the CAPM ((A.1) of Appendix A) in which we used the delevered version of beta ((A.4) of Appendix A), we fixed the equity market risk premium at $5 \%$ level and we take risk-free rate equal to the average 10 years government bond yield of the country in which each bank mainly operates for each year of analysis.

To estimate the value of debt benefits we used a one-stage steady state model. This choice benefits is twofold. First, growth is not taken into account as its estimates - either of idiosyncratic or macroeconomic nature - make the model too volatile and biased by analysts' expectations along the period under investigation; on 
the other side they do not reflect perpetual growth. Second, in DCF two-stage models, generally the terminal value represents the $70-80 \%$ of the value of a company.

We run our version of one-stage asset side valuation model to assess the value of debt benefits for all the banks in our sample (data were available for 24 of them) and then we treated the results aggregating the single estimations. The model is based on the assumption that the market at the end of year already incorporates the analysts' estimations on bank results of the fiscal year in course. An example of the model we used is in Table 2.

As far as cost of capital is concerned, according to the literature concerning ICC estimation methods (among others: Hou et al. 2012, Li \& Mohanram 2014), the valuation method developed in this paper allows to extrapolate the cost of bank assets using the following formula:

$$
\rho_{1}=\frac{X^{\tau}+D_{2}\left[r_{f}-r_{l}(1-\tau)\right]}{V_{2}} .
$$

The reference obtained with (5.2) is compared with the average cost of capital obtained with CAPM for the observation period.

\subsection{Results}

In Fig. 1, we highlight the incidence of present value of debt benefits on enterprise value, using for each year the aggregate values of banks.

Table 2. Example of One-stage model applied in our model.

\begin{tabular}{lccc}
\hline BNP Paribas & 2008 & 2009 & 2010 \\
\hline Market cap & $27.470,0$ & $66.215,0$ & $56.992,7$ \\
Total liabilities & $2.016 .583,0$ & $1.977 .354,0$ & $1.912 .529,0$ \\
Enterprise value & $2.044 .053,0$ & $2.043 .569,0$ & $1.969 .521,7$ \\
FCFA & $15.850,4$ & $14.089,8$ & $16.114,1$ \\
Normalized Net Income & $3.019,7$ & $5.593,3$ & $8.063,4$ \\
Interest expenses (1-t) & $12.830,7$ & $8.496,6$ & $8.050,7$ \\
Cost of asset & 4,30 & 3,84 & 3,30 \\
Risk-free + Country risk & 4,23 & 3,64 & 3,12 \\
Equity beta & 1,04 & 1,25 & 1,29 \\
Market Risk Premium & 5,0 & 5,0 & 5,0 \\
Asset beta & 0,01 & 0,04 & 0,04 \\
Market value of asset & $368.872,1$ & $366.865,4$ & $487.937,9$ \\
Market value of debt benefits & $1.675 .180,9$ & $1.676 .703,6$ & $1.481 .583,9$ \\
\hline
\end{tabular}

Note: Market cap and total liabilities constitute the enterprise value at the end of the year. FCFA is measured summing the Normalized Net Income and the Interest expenses net of the marginal tax rate. Risk-free + Country Risk is equivalent to the average yield of the domestic government 10 years bond. Equity beta is measured at the end of the fiscal year on 5 years weekly returns over the Eurostoxx 600 . Market risk premium is fixed at $5 \%$. Asset beta is estimated using delevered equity beta. 


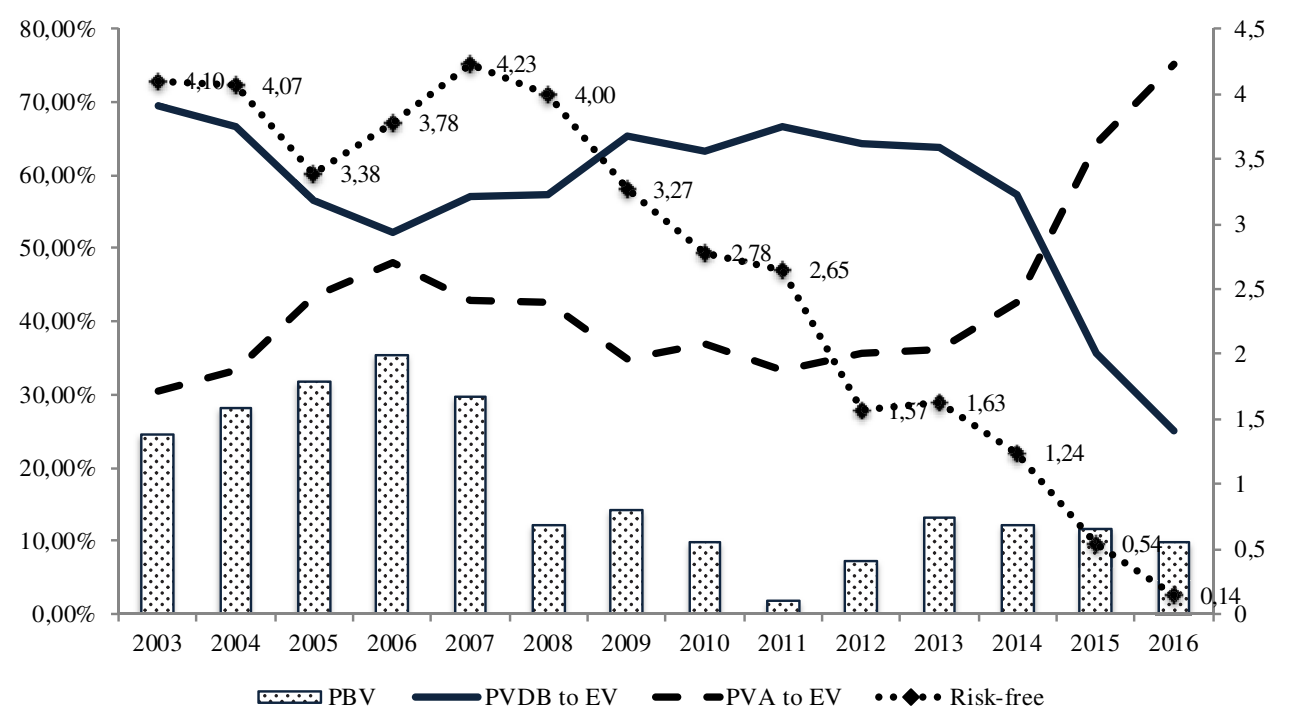

Source: Authors' elaboration.

Fig. 1. Stock markets, debt value and risk-free.

The importance of assigning value to debt can be seen in Fig. 1 By linking the performance of the equity markets (Price to Book Value, PBV), the market value of assets and debt on the enterprise value (respectively Present Value of Debt Benefits, PVDB; Present Value of Asset, PVA) and Risk-free, emerge some relevant evidence.

First, the contribution of the value of the debt benefits to the total enterprise value is always greater than the assets until the level of risk-free is such as to allow to extract adequate level of value from debt. Beyond a level deemed acceptable (in our case $2.78 \%$ ), the contribution of the value of the assets becomes greater than that of the debt as liquidity premium tends to increasingly shrink.

Second, the financial crisis of 2008 shows how the market strongly penalized banks and that during periods of financial turmoil and greater uncertainty - besides increased by the opacity of bank assets — debt and asset's difference in terms of contribution to value is persistent and large. In this market condition assessing the ability to extract value from debt is relatively more straightforward than the assets so that the contribution to value of debt benefits is on average $63.4 \%$ in the 2008 2013 period.

Thirdly, despite the recovery in the market prices of banks and more generally of the financial markets since 2011, the sharp decline in the level of risk-free basically due to the ultra-expansive monetary policy adopted by ECB, kept the multiple on book value of equity far below the unit ( 0.63 on average in the three years period 2014-2016). Although the increase of the value of assets, the stability of the PBV clearly shows how the margins of the banking activity are strongly correlated to 


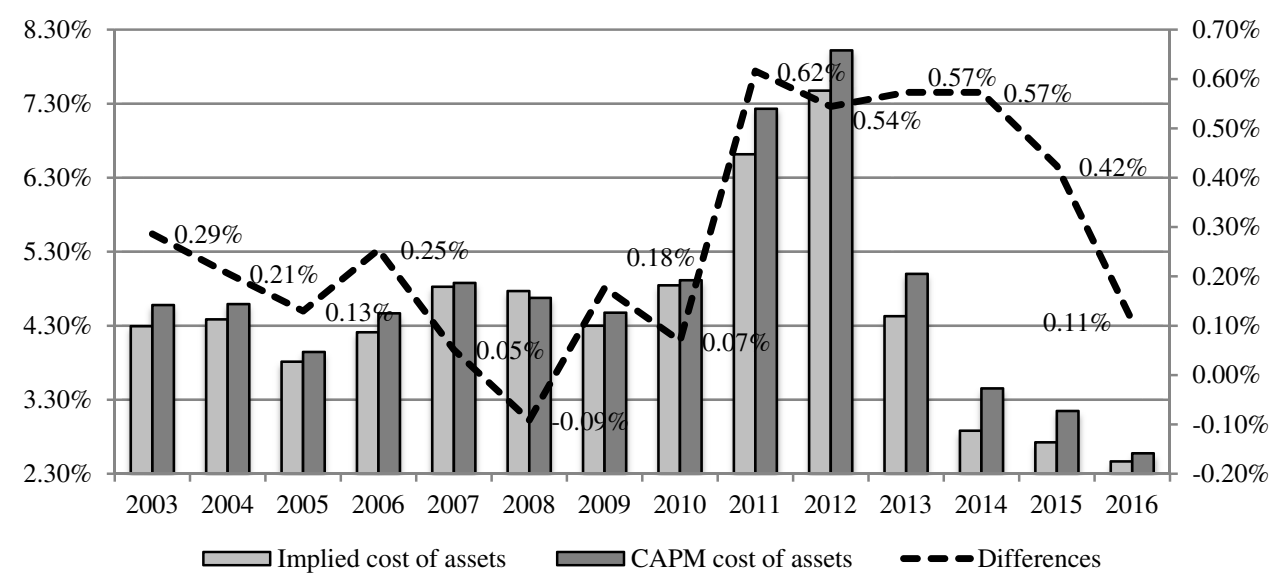

Source: Authors' elaboration.

Fig. 2. Implied cost of assets and CAPM.

risk-free rates and how a zero-rates can strongly compromise bank profitability and value. In such conditions debt benefits account for $24.95 \%$ of the value.

With regard to the estimates we have made regarding the cost of assets, comparing the implicit estimation results in our model with those obtained through the CAPM, the evidence shows substantial consistency between the two methodologies (Fig. 2). The difference in estimations we have obtained is very small. This result is, in the opinion of the authors, positive because our model is not a pricing model, but when it is still used to test its consistency in this regard, it performs substantially as a pricing model, with the advantage of being much simpler and less discretionary to calculate than the CAPM.

However, the risk premium obtained with the CAPM is almost always higher than with the method introduced in this paper. These minimal differences might stem from the intrinsic characteristics of the estimation models. Our model overweights the fundamentals risk at the moment of valuation, while the CAPM tends to incorporate the correlation to systematic risk only more by dragging the historical correlation between security and market at the time of valuation (in our case 5 years back from the time of valuation).

\section{Conclusions}

This paper presents a theoretical framework for bank valuation, reconciling asset and equity side approaches while explicitly taking into account the financial structure and the unique benefits banks obtain from liquidity premium. It formalizes a DCF disaggregate asset-side model showing the contribution of assets and debt to enterprise value. Consistently with the original assumptions of MM's propositions, the segmented markets model is used as in De Angelo \& Stulz (2015), but it differs in 
three main aspects. First, using MM's original arbitrage proof, it is shown how to determine the equity value of a bank using an indirect approach to valuation (Hanson et al. 2015). Unlike most applied valuation metrics, this enables to split value creation between assets and liabilities. Second, the presence of risky assets, rather than just hedged assets, is assumed, in order to take into account the riskiness of cash flows from assets, which is a realistic assumption in a context of valuation. Third, the cost of capital implications when the liquidity premium and taxes come into play is derived. This shows how the mark-down spread mitigates the effect of increasing leverage on the cost of equity.

On this basis, it might be concluded that MM's irrelevance principle is not valid for banks owing to the liquidity premium banks gain on marked-down financial instruments, which makes the choices on financial structure relevant in terms of value. According to MM's first proposition with taxes, total bank value is the sum of the stand-alone asset value and debt advantages (Miller 1995). In addition, the cost of capital implications are in line with MM's partial off-set, which can be highlighted empirically. These conclusions lay the foundation for a theory of leverage-bank cost of capital and for a bank-specific valuation scheme based on asset and debt cash flows in which the total value is a function of the present value of cash flows from asset, tax benefits and the liquidity premium, similarly to the APV of Myers (1974) and the CCFs of Ruback (2002) applied in the valuation of industrial firms. Additionally, we contribute to the literature by presenting the model both in a steady state and steady growth scenarios, providing a reconciliation between asset-side model and the equity DCF methods.

We also presented the results of an empirical application of one-stage asset-side valuation derived by our model finding evidence that debt benefits represents almost the larger portion of the enterprise value of banks until the risk-free rate is considered acceptable for extracting value from deposits. Then our model helps to explain why banks even when assets destroy value or operates with limited buffers of capital might anyway hold a positive value. In this sense, our model can represent a useful method to assess the market value of debt. In addition, results confirm that macroeconomic conditions affect bank value through interest rates. Lower interest rates reduce the value created by mark-down and fiscal benefits on debt. The closer the liquidity premium moves to zero and the more neutral the fiscal effect, in the absence of distress costs, the more irrelevant the choice between equity and debt. However, in the presence of distress costs, increasing regulatory capital in the form of equity becomes the most appropriate source of funding for reducing such costs (Allen et al. 2015, Admati \& Hellwig 2013). Equity can generate value because the decrease in debt benefits is more than compensated for by the decrease in the present value of distress costs. Empirical evidence highlights a positive correlation between bank value and equity capital, owing to the lower probability of being closed (Mehran \& Thakor 2011). In fact, as the probability of default increases, the negative effect on the bank's value is twofold: on the one hand, the present value of distress costs reduces the value of the bank; on the other hand, as the event of default 
approaches, it reduces the generation of the liquidity premium, since the latter is totally given when the debt is perceived as not risky.

Lastly, this paper provides an ICC method which is an useful instruments to assess the cost of assets instead of the CAPM. Results show a strong correlation between the two with very small differences, with the advantage that our ICC estimation does not incorporate historical correlation of the single security with the market portfolio and is less dependent to discretional choices.

On the whole the theoretical framework presented in this paper has useful applications in bank valuation. First, compared to the currently applied DCF equity-side models, the disaggregate perspective to valuation reveals more clearly where, between assets and liabilities, the value of a bank is generated. Other equity-side methods lack such useful information, providing only a synthetic view of value creation. More specifically, the minimum regulatory requirements that banks must comply with do not negate the need to analyze the effects of financial structure on value, as banks can create value not only by choosing between equity and debt, but also by choosing between several types of debt financial instruments available for each special category of firm, on which depends the size of the liquidity premium. Second, the disaggregate model does not require the assumptions typical of the DCF equity side methods, namely the distribution of the excess capital, the adjustments for such capital distribution, a stable capital structure in the forecast period and the assumption on the level of distributable earnings. A financial analyst or bank manager could benefit from the method explicitly reflecting changes in capital requirements or different bank leverage policies in bank valuation.

The main limitation of the model is that it does not take into account the present value of distress costs. Future research is called to introduce this effect into the bank valuation scheme, formalizing a trade-off between debt advantages (liquidity premium and tax-shields) and disadvantages in term of distress costs.

\section{Appendix A. Systematic Risk and Leverage: Determining the Cost of Unlevered Bank}

A separate determination of bank unlevered value requires the use of the unlevered cost of equity $\left(\rho_{1}\right)$ to discount the asset cash flows. The cost of equity for the unlevered firm is generally unobservable due to the presence of levered firms in the financial market. Assuming a perfectly diversified investor, we can express $\rho_{1}$ through the CAPM relation:

$$
\rho_{1}=r_{f}+\beta_{U}\left(r_{m}-r_{f}\right),
$$

where $\beta_{U}$ is the beta of the unlevered bank, and where $r_{m}$ is the return of the market portfolio. Allowing the CAPM, the problem shifts to the calculation of the unlevered beta. 
Hamada (1972) introduced a model to determine an unlevered (or asset) beta combining MM's second proposition and the CAPM. Assuming that the beta of debt is zero (in line with prior studies analyzing the effect of leverage on bank overall cost of capital) and debt benefits are discounted using at the unlevered cost of capital, we can establish the relation between levered and unlevered beta as:

$$
\beta_{E}=\beta_{U}\left(1+\frac{D}{S}\right) .
$$

Alternatively, when debt is fixed and debt benefits are discounted at the cost of debt (risk-free rate), Equation (5.2) becomes:

$$
\beta_{E}=\beta_{U}\left[1+(1-\tau) \frac{r_{l}}{r_{f}} \frac{D}{S}\right] .
$$

Independently of whether debt benefits are discounted at the cost of unlevered capital, the Hamada equation is the same of the case of non-financial firm. In contrast, equity betas are affected by taxes and by the difference between the risk-free rate and the cost of core deposits. Inverting the two relations, we reach the unlevered beta in the two different basic assumptions, respectively:

$$
\begin{gathered}
\beta_{U}=\frac{\beta_{E}}{\left(1+\frac{D}{S}\right)}, \\
\beta_{U}=\frac{\beta_{E}}{\left[1+(1-\tau) \frac{r_{l}}{r_{f}} \frac{D}{S}\right]} .
\end{gathered}
$$

\section{Appendix B. A Comparison Between the Asset Cash Flow Method and Flow to Equity Model}

The following example based on data in Table B.1 provides a comparison in terms of application of the asset cash flow method and flow to equity model. The example aims to demonstrate that if the cost of equity is not consistently determined over time, significant mistakes in valuation can occur. We assume the absence of taxes and growth in the terminal value and require an increasing level of capital requirement (Tier 1) covered by equity.

Applying the asset cash flow method, the bank unlevered value is

$$
\begin{aligned}
V_{1}= & \frac{\mathrm{FCFA}}{\left(1+\rho_{1}\right)}+\frac{\mathrm{FCFA}}{\left(1+\rho_{1}\right)^{2}}+\frac{\mathrm{FCFA}}{\left(1+\rho_{1}\right)^{3}}+\frac{\mathrm{FCFA}}{\left(1+\rho_{1}\right)^{4}}+\frac{\mathrm{FCFA}}{\rho_{1}} \frac{1}{\left(1+\rho_{1}\right)^{4}} \\
= & \frac{29,500}{(1+3.42 \%)}+\frac{29,500}{(1+3.42 \%)^{2}}+\frac{29,500}{(1+3.42 \%)^{3}}+\frac{29,500}{(1+3.42 \%)^{4}} \\
& +\frac{29,500}{3.42 \%} \frac{1}{(1+3.42 \%)^{4}}=862,573 .
\end{aligned}
$$


Table B.1. Balance sheet and financial market data.

\begin{tabular}{lccccc}
\hline In $€$ & 1 & 2 & 3 & 4 & 00 \\
\hline $\begin{array}{l}\text { Account value of } \\
\quad \text { assets (t) }\end{array}$ & $1,000,000,000$ & $1,000,000,000$ & $1,000,000,000$ & $1,000,000,000$ & $1,000,000,000$ \\
Risk weighted assets & $50 \%$ & $50 \%$ & $50 \%$ & $50 \%$ & $50 \%$ \\
$\quad$ density (t) & & & & & \\
Target Tier 1 ratio (t) & $12 \%$ & $13 \%$ & $14 \%$ & $15 \%$ & $15 \%$ \\
Targete account value & $60,000,000$ & $65,000,000$ & $70,000,000$ & $75,000,000$ & $75,000,000$ \\
$\quad$ & & & & $925,000,000$ \\
of Equity (t) & $940,000,000$ & $935,000,000$ & $930,000,000$ & 925,000 & 925,000 \\
Target Debt (t) & $29,500,000$ & $29,500,000$ & $29,500,000$ & $29,500,000$ & $29,500,000$ \\
FCFA (t) & $3.42 \%$ & $3.42 \%$ & $3.42 \%$ & $3.42 \%$ & $3.42 \%$ \\
Risk-free rate & $3.00 \%$ & $3.00 \%$ & $3.00 \%$ & $3.00 \%$ & $3.00 \%$ \\
Return on debt & $2.50 \%$ & $2.50 \%$ & $2.50 \%$ & $2.50 \%$ & $2.50 \%$ \\
\hline
\end{tabular}

Note: Book value, expected return on asset and risk weighted assets are fixed. After Period 4 a steady state scenario is adopted. The main hypothesis is a progressive replacement of debt with equity, according to an expected growth of Tier 1 ratio from $12 \%$ to 15\%. As a consequence, some repayments of debt through shareholder capital are expected. FCFA are free cash flows from assets.

The present value of debt benefits (in this case represented by a liquidity premium since we are assuming the absence of taxes) is

$$
\begin{aligned}
\mathrm{PVDB}= & D_{0} \frac{r_{f}-r_{l}}{\left(1+\rho_{1}\right)}+D_{1} \frac{r_{f}-r_{l}}{\left(1+\rho_{1}\right)^{2}}+D_{2} \frac{r_{f}-r_{l}}{\left(1+\rho_{1}\right)^{3}}+D_{3} \frac{r_{f}-r_{l}}{\left(1+\rho_{1}\right)^{4}}+D_{4} \frac{r_{f}-r_{l}}{\rho_{1}} \frac{1}{\left(1+\rho_{1}\right)^{4}} \\
= & 940,000 \frac{3 \%-2.50 \%}{(1+3.42 \%)}+940,000 \frac{3 \%-2.50 \%}{(1+3.42 \%)^{2}}+935,000 \frac{3 \%-2.50 \%}{(1+3.42 \%)^{3}} \\
& +930,000 \frac{3 \%-2.50 \%}{(1+3.42 \%)^{4}}+925,000 \frac{3 \%-2.50 \%}{3.42 \%} \frac{1}{(1+3.42 \%)^{4}}=135,444 .
\end{aligned}
$$

The bank firm value is

$$
V_{2}=V_{1}+\mathrm{PVDB}=862,573+135,444=998,017
$$

while value of equity is

$$
S_{2}=V_{2}-D_{2}=998,017-940,000=58,017 .
$$

Table B.2. Cash flow statement.

\begin{tabular}{lccccc}
\hline Data in $€$ & 1 & 2 & 3 & 4 & 00 \\
\hline FCFA & $29,500,000$ & $29,500,000$ & $29,500,000$ & $29,500,000$ & $29,500,000$ \\
Interest expenses & $23,500,000$ & $23,500,000$ & $23,375,000$ & $23,250,000$ & $23,125,000$ \\
Debt repayment & - & $5,000,000$ & $5,000,000$ & $5,000,000$ & - \\
FCFE & $6,000,000$ & $1,000,000$ & $1,125,000$ & $1,250,000$ & $6,375,000$ \\
\hline
\end{tabular}

Note: In the absence of taxes, the free cash flow to equity is given by netting free cash flow from assets of interest expenses and debt repayments. Interest expenses are calculated on the debt at the beginning of the year using the cost of debt. 
Moving toward a flow to equity method, we calculate first the cost of equity and then the equity value

$$
i_{2}=\rho_{1}+\left(\rho_{1}-r_{f}\right) \frac{D_{2}}{S_{2}}=3.42 \%+(3.42 \%-3 \%) \frac{940,000}{58,017}=10.22 \% .
$$

In order to directly reach the value of equity, we need to know the free cash flow to equity. In Table B.2 we provide a summary of a cash flow statement.

The equity value is determined as

$$
\begin{aligned}
S_{2}= & \frac{\mathrm{FCFE}_{1}}{\left(1+i_{2}\right)}+\frac{\mathrm{FCFE}_{2}}{\left(1+i_{2}\right)^{2}}+\frac{\mathrm{FCFE}_{3}}{\left(1+i_{2}\right)^{3}}+\frac{\mathrm{FCFE}_{4}}{\left(1+i_{2}\right)^{4}}+\frac{\mathrm{FCFE}_{4}}{i_{2}} \frac{1}{\left(1+i_{2}\right)^{4}} \\
= & \frac{6000}{(1+10.22 \%)}+\frac{1000}{(1+10.22 \%)^{2}}+\frac{1125}{(1+10.22 \%)^{3}}+\frac{1250}{(1+10.22 \%)^{4}} \\
& +\frac{6375}{10.22 \%} \frac{1}{(1+10.22 \%)^{4}}=50,217 .
\end{aligned}
$$

As we noted above, unless the cost of equity is stated consistent with leverage changes, the result of the flow to equity model is misleading. In Table B.3, we report the dynamics of leverage ratio and the consistent changes in cost of equity.

Using the correct cost of equity for each year, we arrive at an equity value consistent with that of the asset cash flow model

$$
\begin{aligned}
S_{2}= & \frac{\mathrm{FCFE}_{1}}{\left(1+i_{2,1}\right)}+\frac{\mathrm{FCFE}_{2}}{\left(1+i_{2,1}\right)\left(1+i_{2,2}\right)}+\frac{\mathrm{FCFE}_{3}}{\left(1+i_{2,1}\right)\left(1+i_{2,2}\right)\left(1+i_{2,3}\right)} \\
& +\frac{\mathrm{FCFE}_{4}}{\left(1+i_{2,1}\right)\left(1+i_{2,2}\right)\left(1+i_{2,3}\right)\left(1+i_{2,4}\right)}+\frac{\mathrm{FCFE}_{4}}{i_{2, \infty}} \frac{1}{\left(1+i_{2,1}\right)\left(1+i_{2,2}\right)\left(1+i_{2,3}\right)\left(1+i_{2,4}\right)} \\
= & \frac{6000}{(1+10.22 \%)}+\frac{1125}{(1+10.22 \%)(1+10.23 \%)}+\frac{1250}{(1+10.22 \%)(1+10.23 \%)(1+9.67 \%)} \\
& +\frac{1}{(1+10.22 \%)(1+10.23 \%)(1+9.67 \%)(1+9.18 \%)} \\
& +\frac{6375}{8.76 \%} \frac{1}{(1+10.22 \%)(1+10.23 \%)(1+9.67 \%)(1+9.18 \%)}=58,017 .
\end{aligned}
$$

Table B.3. Leverage and cost of equity dynamic.

\begin{tabular}{lccccc}
\hline Data in $€$ & 1 & 2 & 3 & 4 & 00 \\
\hline Bank unlevered value & $862,573,099$ & $862,573,099$ & $862,573,099$ & $862,573,099$ & $862,573,099$ \\
Present value of debt benefits & $135,443,615$ & $135,375,787$ & $135,305,639$ & $135,258,091$ & $135,233,918$ \\
Bank firm value & $998,016,714$ & $997,948,886$ & $997,878,738$ & $997,831,191$ & $997,807,018$ \\
Present value of debt (t-1) & $940,000,000$ & $940,000,000$ & $935,000,000$ & $930,000,000$ & $925,000,000$ \\
Equity & $58,016,714$ & $57,948,886$ & $62,878,738$ & $67,831,191$ & $72,807,018$ \\
D/E & 16.20 & 16.22 & 14.87 & 13.71 & 12.70 \\
Cost of equity & $10.22 \%$ & $10.23 \%$ & $9.67 \%$ & $9.18 \%$ & $8.76 \%$ \\
\hline
\end{tabular}

Note: The present value of debt benefits is calculated using the liquidity premium applied to debt at the beginning of the year and discounted at the expected return of assets. 


\section{Acknowledgements}

We thank for their helpful suggestions and comments: Alessandro Carretta, Mario Comana, Aswath Damodaran, Harry De Angelo, Mike Dempsey, Vincenzo Farina, Caterina Lucarelli, Gianluca Mattarocci, Maurizio Polato, Federica Poli, Raffaele Oriani, Alex Sclip, Simone Rossi, Laura Zanetti and participants at the 2017 EFMA Conference (Athens), the 2016 Porthsmouth-Fordham "Banking \& Finance" Conference and the 2016 Wolpertinger and ADEIMF Conferences. The view expressed in this paper is that of the authors only.

\section{References}

F. Allen, E. Carletti \& R. Marquez (2015) Deposits and bank capital structure, Journal of Financial Economics 118, 601-619.

A. Admati \& M. Hellwig (2013) The Bankers' New Clothes: What's Wrong with Banking and What To Do About It. Princeton: Princeton University Press.

E. R. Arzac \& L. R. Glosten (2005) A reconsideration of tax shield valuation, European Financial Management 11, 453-461.

M. Baker \& J. Wurgler (2015) Do strict capital requirements raise the cost of capital? Bank regulation, capital structure, and the low risk anomaly, The American Economic Review 105, 315-320.

M. Bank \& J. Lawrenz (2013) Deposit finance as a commitment device and the optimal debt structure of commercial banks, European Financial Management 19, 14-44.

R. G. Barker (1999) Survey and market-based evidence of industry-dependence in analysts' preferences between the dividend yield and price-earnings ratio valuation models, Journal of Business Finance \& Accounting 26, 393-418.

F. Beltrame \& D. Previtali (2016) Valuing Banks: A New Corporate Finance Approach, Palgrave McMillan, London.

I. A. Cooper \& K. G. Nyborg (2006) The value of tax shield is equal to the present value of tax shields, Journal of Financial Economics 81, 215-225.

T. E. Copeland, T. Koller \& J. Murrin (2000) Valuation Measuring and Managing the Value of Companies. New York: John Wiley \& Sons.

A. Damodaran (2013) Valuing financial service firms, Journal of Financial Perspectives, 1, $1-16$.

H. De Angelo and R. M. Stulz (2015) Liquid-claim production, risk management, and bank capital structure: Why high leverage is optimal for banks, Journal of Financial Economics 116, 219-236.

M. Dempsey (2013) Consistent cash flow valuation with tax-deductible debt: A clarification, European Financial Management 19, 830-836.

D. W. Diamond \& P. H. Dybvig (1983) Bank runs, deposit insurance, and liquidity, The Journal of Political Economy 91, 401-419.

D. W. Diamond \& R. G. Rajan (2001) Banks and liquidity, The American Economic Review 91, 422-425.

P. Fernández (2004) The value of tax shields is NOT equal to the present value of tax shields, Journal of Financial Economics 73, 145-165.

G. B. Gorton, (2010) Slapped by the Invisible Hand: The Panic of 200\%. Oxford: Oxford University Press.

G. B. Gorton \& G. Pennacchi (1990) Financial intermediaries and liquidity creation, The Journal of Finance 45, 49-71. 
S. G. Hanson, A. K. Kashyap \& J. C. Stein (2011) A macroprudential approach to financial regulation, The Journal of Economic Perspectives 25, 3-28.

S. G. Hanson, A. Shleifer, J. C. Stein \& R. W. Vishny (2015) Bank as patient fixed-income investors, Journal of Financial Economics 117, 449-469.

R. S. Hamada (1972) The effect of the firm's capital structure on the systematic risk of common stocks, The Journal of Finance 3, 435-452.

R. S. Harris \& J. J. Pringle (1985) Risk adjusted discount rates - extension from the average risk case, Journal of Financial Research 8, 237-244.

B. Holmström \& J. Tirole (2011). Inside and Outside Equity. Cambridge: MIT Press.

K. Hou, M. A. van Dijk \& Y. Zhang (2012) The implied cost of capital: A new approach, Journal of Accounting Economics 53, 504-526.

S. Imam, R. Barker \& C. Clubb (2008) The use of valuation models by UK investment analysts, European Accounting Review 17, 503-535.

I. Inselbag \& H. Kaufold (1997) Two DCF approaches for valuing companies under alternative financing strategies (and how to choose between them), Journal of Applied Corporate Finance 10, 114-122.

A. K. Kashyap, J. C. Stein \& S. G. Hanson (2010) An analysis of the impact of 'substantially heightened' capital requirements on large financial institutions, Working paper, Booth School of Business University of Chicago.

K. K. Li \& P. Mohanram (2014) Evaluation cross-sectional forecasting models for implied cost of capital, Review of Accounting Studies 19, 1152-1185.

M. Massari, G. Gianfrate \& L. Zanetti (2014) The Valuation of Financial Companies: Tools and Techniques to Measure the Value of Banks, Insurance Companies and Other Financial Institutions. New York: John Wiley \& Sons.

M. Massari, F. Roncaglio \& L. Zanetti (2008) On the equivalence between the APV and the WACC approach in a growing leveraged firm, European Financial Management 14, 152162.

M. Massari \& L. Zanetti (2008) Valutazione: Fondamenti teorici e best practice nel settore industriale e finanziario, McGraw-Hill, Milan.

H. Mehran \& A. Thakor (2011) Bank capital and value in the cross-section, Review of Financial Studies 24, 1019-1067.

R. Merton (1990) Continuous-Time Finance. Oxford: Blackwell.

D. Miles, J. Yang \& G. Marcheggiano (2013) Optimal bank capital, The Economic Journal 123, $1-37$.

J. A. Miles \& J. R. Ezzell (1980) The weighted average cost of capital, perfect capital markets and project life: A clarification, Journal of Financial and Quantitative Analysis 15, 719-730.

M. H. Miller (1995) Do the M \& M propositions apply to banks? Journal of Banking \& Finance $19483-489$.

F. Modigliani \& M. H. Miller (1958) The cost of capital, corporation finance and the theory of investment, The American Economic Review 48, 261-297.

F. Modigliani \& M. H. Miller (1963) Corporate income taxes and cost of capital, The American Economic Review 53, 433-443.

S. C. Myers (1974) Interactions of corporate financing and investment decisions - implications for capital budgeting, The Journal of Finance 29, 1-25.

B. Rosenberg \& P. R. Perry (1978) The fundamental determinants of risk in banking, Working paper, NBER Cambridge.

R. S. Ruback (2002) Capital cash flow: A simple approach to valuing risky cash flows, Financial Management 31, 53-70.

R. A. Taggart (1991) Consistent valuation and cost of capital expressions with corporate and personal taxes, Financial Management 20, 8-20. 